\title{
Research on Optimizing the Training System of Foreign Language Dual - Initiative Talents under the Belt and Road Initiative
}

\author{
Wei Meng \\ Shandong College of Tourism and Hospitality, Ji'nan, Shandong, 250200
}

Keywords: Training System, Foreign Language Dual - Initiative Talents, the Belt and Road Initiative

\begin{abstract}
Under the Belt and Road Initiative, the rapid development of tourism poses higher requirements for tourism practitioners. Talent is the fundamental cause of tourism. Building a contingent of highly qualified personnel is a top priority for tourism. Tourism personnel training made a significant breakthrough in 2015. The National Tourism Administration puts forward the "515 Strategy", which has worked out concrete plans in basic personnel system construction, professional personnel training and high-level backbone personnel training. The purpose of this paper is to explore the optimization of the training system for double language talents in tourism foreign language under the Belt and Road Initiative.
\end{abstract}

\section{Introduction}

Under the "Belt and Road Initiative", Chinese tourism industry maintained a steady and rapid development. Inbound tourism market achieved steady growth, and the outbound tourism market continued to grow rapidly. A total of 135 million inbound tourists were received in the year, achieving an international tourism (foreign exchange) income of 48.464 billion U.S. dollars, up by $1.2 \%$ and $5.8 \%$ over the previous year respectively. The number of Chinese citizens leaving the country reached 70.25 million, an increase of $22.4 \%$ over the previous year. The foreign tourists market grew steadily. The number of foreign tourists arriving abroad in the year was 27.111 million, an increase of 3.8\% over the same period of last year. The Asian market is still the major source market, accounting for $61.7 \%$ of the total number of overseas residents, up $2.8 \%$ over the previous year; the European market increased by $4.2 \%$ over the previous year, the Americas increased by $6.9 \%$, the Oceania increased by $8.9 \%$ and the Africa increased by $5.4 \% \%$. Statistics from the China National Tourism Administration show that the tourism market's demand for foreign-related tourism talent is on an unprecedented increase. Tourism talent plays an important role in the tourism business, affecting the entire tourism process. It is a long-term and continuous task and task to create qualified people with good foreign language skills and tourism expertise that are suitable for market competition and tourism development [1].

As of the end of 2011, there were 1115 higher education institutions of higher learning and tourism departments (majors) in the country, an increase of 148 from the previous year, with 599,800 students, an increase of 37,000; and 1093 secondary vocational schools, By the end of last year, an increase of 92, with 483,400 students, a decrease of 6,900. Taken together, the total number of 2208 tourism colleges and universities is 1,083,300 students. The total number of in-service staff in the entire industry reached 4.3565 million, an increase of 90,000 from the previous year, an increase of $2.1 \%$. After years of efforts, many colleges and universities have explored foreign-related tourism teaching modes that are suitable for their actual conditions. A number of research achievements have also emerged in the course reform of the curriculum. However, domestic colleges and universities have not explored enough in the reform of foreign- Mainly manifested in: (1) the theoretical curriculum; (2) teacher discipline; (3) the lack of personnel training and regional service industry organic combination. 


\section{The Status Quo and Problems of Training of Tourism English Talent}

Applied undergraduate education belongs to a higher level of technical education and is an important part of higher education in our country [2]. In terms of training standards, applied undergraduate education is not a subject, academic, research personnel, but to train students to adapt to production, construction, management, service needs of the first-line high-tech talents; in training mode, application in order to meet the needs of society, the undergraduate designs the students 'knowledge, abilities, quality structure and training programs based on the cultivation of technical application ability. The curriculum and teaching content system is constructed based on the "application" principle and features, and emphasis is placed on the training of students' technical application ability. Applied undergraduate colleges in the training of tourism professionals in English, should be particularly prominent professional and level of applicability that graduates can engage in both entry and exit of English and Chinese tour guides, but also engaged in tourism management, hotel services and other aspects of work. Applied undergraduate colleges each year train a large number of tourism English graduates, quantitatively speaking, to better meet the needs of foreign language talents of tourism economy development. However, the problem of the disconnection between school education and social needs has not been solved well. The ability and level of graduates are repeatedly criticized. On the one hand, there is a strong need for tourism English talents; on the other hand, many graduates of this major cannot find the ideal job, are we over-qualified? Obviously, the responsibility of the school cannot be dunked. How we cultivate talents today undoubtedly deserves reflection and makes the right choice in all colleges and universities.

Curriculum and teaching content outdated. At present, most of the applied undergraduate tourism English major training target positioning is too high, the scope is too wide, the teaching plan ignores the practice ability and humanistic quality of students. The contents of other related disciplines are generally ignored in the curriculum arrangement and teaching content arrangement. The structure of teaching contents and teaching materials is single and the contents are old and aging. Some colleges and universities copied the teaching model of subject-oriented college English, which is merely the deletion of classes or the superposition of curriculums. It does not really design students' knowledge, abilities, quality structure, theoretical teaching, practical teaching and practical teaching based on the cultivation of technical application ability and professional quality three systems of quality education have not really established. As a result, it is difficult to cultivate the complex and applied tourism management talents urgently needed by the society due to the shortcomings such as not wide field of vision, weak heritage, weak skill, low stamina, low personality, Cause excess of graduates.

We should be in line with the application of undergraduate specialty textbook serious shortage. The current application of undergraduate education travel English teaching materials, one source borrowed undergraduate textbooks, cut-off by the teachers, supplemented and made; second is the application of higher vocational teaching materials or textbooks based on the higher vocational content. These textbooks only focus on the changes in content, excessive emphasis on the systematic knowledge, the basic theoretical weight is too heavy, the proportion of applied skills is light, did not fundamentally reflect the characteristics and requirements of applied undergraduate teaching, not suited to apply undergraduate education students need. Tourism English professional teaching methods, evaluation method is relatively simple. In some applied undergraduate colleges and universities in our country, instillation teaching and one-roll examination methods are still commonplace. The training of students in colleges and universities is rather indoctrination of knowledge and neglect of personality development. Has been shouting the reform of teaching methods, evaluation system, but thunder, rain is small, the cultivation of student skills in practice has not really reflected. In the context of the popularization of higher education, strengthening the cultivation of students' practical skills should and effectively become the goal of applied-type undergraduate education and the focus of education reform in the future. However, it is obvious that the cultivation of these skills depends on the traditional single teaching method and appraisal 
method effective implementation [3].

With the substantial increase in the number of higher education, college entrance barriers to lower. The students who enter the applied undergraduate colleges basically follow the college entrance examination volunteer test to the applied undergraduate colleges. The students' interest in studying after entering the school is not strong and the spirit of hard work is poor. Students generally think that the major they study has little to do with future work and life ideal, These factors directly led to the students weaken the subjective initiative learning, do not love to learn, the ability to adapt to the market is weak.

There is a lack of natural connection between schools and businesses. In the aspect of industry-university-research integration, due to the lack of motivation, lack of policy support and the lack of long-term goals, both businesses and schools cannot intervene deeply and have not established a mutual promotion and mutual benefit mechanism. Making the actual operation of the combination of production and study is only students to enterprises to complete the training course, far from a virtuous circle, the effect of its operation has not established a suitable system. In a nutshell, the process of cultivating applied undergraduate students is suspicious of being behind closed doors both in theory and in application, with poor applicability, narrow export and low social recognition. Students do not accept or do not love to learn but cannot but choose Road, have to learn. Here we may wish to apply the undergraduate colleges and students training process and students were compared to the bike, gears and chains, the car gear and the chain have a lot of cracks, not tight bite, did not force the same goal, this time the bike If not promptly repaired, it can only be mixed and live in the mix.

\section{Chinese Tourism English Talent Training Strategies}

The school to run a feature, the key is to have a professional specialty. To cultivate the social satisfaction of the advanced application-oriented talents, we must maintain the flexibility of the curriculum system. Applied undergraduate colleges and universities should strictly follow the characteristics and needs of occupational clusters or industries and enterprises to determine the curriculum [4]. According to the knowledge, skills and quality requirements of the society, the curriculum should be adjusted according to the needs of individual development and the specialty of tourism English. On the basis of the theory enough, enhance the flexibility of the curriculum, pay attention to the development of student's personality and the need of occupational adaptability. Focus on students' vocational skills training so that students can better grasp the professional skills and work immediately after graduation. English Department of Shenyang Institute of Technology in the course of setting up courses, employ experts and business personnel to participate in the curriculum design of the school, reduce the courses not related to employment and quality training, and increase the special courses that the society needs. The course aims at cultivating students' English communicative competence and tourism operation ability as the main starting point and ending point. According to the actual conditions of the students, the course reform and integration, the professional courses are divided into two series, three kinds of nature. The three properties refer to professional basic courses, professional skills courses and professional development courses. Professional basic courses mainly through classroom teaching students to master the mastery of theoretical knowledge, improve the depth and breadth of student knowledge. Professional skills mainly teach tourism-related knowledge and skills, and through practical teaching and extra-curricular training to train and improve the practical ability of students. Professional Development Section Through a large number of elective courses to expand the knowledge base and increase students' understanding of professional knowledge.

We should take effective measures to improve the application of undergraduate English teaching material system of tourism. The compilers of tourism English textbooks for applied undergraduate colleges should intensify their investigation and study of production practice, strengthen the scientific analysis of the professional knowledge and professional ability required for professional posts, explore the scientific support for curriculum theory, and compile a series of rich Flexible authority textbook; at the same time to encourage teachers to compile their own textbooks to avoid 
the textbook system is unknown, the contents of the cross, from the actual problems; more attention should be paid and professional textbooks supporting the preparation of training materials. The compilation of tourism English teaching materials must take into account the following three aspects: First, the content is new, the system is complete. Each course should be reasonable division of labor, interlinked to form a more complete system. This not only highlights the cross-penetration of the knowledge system framework and knowledge points, but also takes into account the logical relationship between the various courses. On the one hand, the arrangement of content structure system embodies a gradual process from simple to complex, from easy to difficult, suitable for both teaching and learning, advancing with the times, arranging course contents according to actual needs and technological development; on the other hand, In the content selection and style arrangements have fully considered the application of undergraduate knowledge structure needs. In the form, structure, content and try to reflect the three aspects of innovation, to avoid simple repetition with similar materials. Second, give prominence to reality and operability. For the application-oriented personnel training objectives are often located in the training of high-quality applied talents, which is characterized by strong knowledge of the ability and ability to innovate, therefore, the teaching materials should be written on the practicality of teaching materials and teaching effectiveness, pay attention to changes in teaching mode, teaching content updates and teaching methods. Attention should be given to cultivating students' independent thinking, independent handling of business and practical ability and excellent technology of solving problems independently. Thus, the preparation of teaching materials, and strive to make students adapt to the structure of knowledge and ability to closely meet the needs of economic and social development, with strong professional competitiveness. In addition to strengthening the basic knowledge and basic skills of students, teaching materials should pay attention to students' practical ability, comprehensive analysis ability and ability of innovation, guide students to break the routine, be creative, and integrate quality education into teaching materials. Teachers in the completion of the necessary knowledge and skills training, at the same time, students develop their own learning ability and ability to innovate [5].

According to local conditions to establish an unique English teaching personnel training methods. Through five years of teaching practice in tourism English, the author believes that to improve the teaching of tourism English, we must first strengthen the teaching of spoken language classes and listening comprehension, put the listening and speaking in a prominent position. Second, we should strengthen the teaching of English applied writing class. Tourism English graduates will handle a wide range of documents, forms and correspondence in their future jobs. This ability should be trained through English writing lessons at school. Applied Writing Course should highlight the professionalism of tourism English, through the selection of teaching materials, so that students familiar with the common vocabulary of tourism, learning sentence patterns commonly used sentences, a variety of file formats and tabular format. In addition, we should also emphasize practical teaching links, strengthen the links between tourism English major and foreign tourism enterprises, and increase students' practical opportunities to meet the needs of employers and graduates for job hunting. Practical teaching links include classroom practice, school practice and off-campus practice in three areas. Classroom practice includes class discussions, class presentations, travel case studies, and guided tour of English and Chinese tutorials based on teaching content and tasks; in-school practices include various forms of English extracurricular activities such as simulated travel agencies, simulated hotels, English speaking competitions, English essay competitions and so on. The practice outside the school is mainly to fully exploit resources and try to strengthen contact with major medium-sized travel agencies, star-rated hotels and tourist attractions so as to open up training bases for students. On the one hand, students can be trained in practical skills; on the other hand, teachers and students can also provide a stage to display their talent. Broaden employment opportunities and attract outstanding students. Applied undergraduate education must be bigger and stronger, so that students can really learn professional skills, have a skill have a better career path, in order to attract outstanding students. College only positive action, training and improve the professional competitiveness of students is the key. 
Rationally plan the professional development direction of tourism English majors, organize vocational skills training, encourage students to learn beyond the campus, participate in social practice, improve practical ability, understand the needs of society, which will help broaden students' job hunting path.

\section{Conclusions}

Improve the training model of tourism English should focus on the long term, the relevant educators need to continue to summarize in practice, continuous improvement, and take effective countermeasures so that tourism English can truly meet the needs of society, and more for the community to develop a tourism practical expertise of management expertise, complex talents. Through our education the students can grow and improve to find their own ability to find employment.

\section{Acknowledgements}

Fund Project: Shandong Educational Science Research Program (No. 17sc040). Research Program of Vocational Education Reform in Shandong Province (No. 2017657). Ten Thousand Tourism Talents Program Supported by China National Tourism Administration (No. 2016150)

\section{References}

[1] Tong Mingjia. Optimization of tourism foreign language talent cultivation system in the era of big data[J]. Tourism Overview (second half). 2017 (12).129

[2] Xiong Xiao-hong. Discussion on the Cultivation Mode of Foreign Language Applied Talents in Colleges and Universities[J]. Journal of Campus English 2016 (34).63

[3] Dong Hui, Beijing, Tianjin and Hebei under the context of coordinated development of foreign language talent needs and training strategies[J]. Lanzhou Institute of Education. 2017 (05).45

[4] Wang Jiao. Reflections on Cultivating Foreign Language Talents in Applied Universities under the New Situation[J]. Popular Bohai Economic Outlook. 2017 (07).456

[5] Liu Xun. Factors and ways of cultivating international innovative foreign language talents[J]. Journal of Heihe University. 2017 (04).33 